\title{
Quantification of Short-Chain Free Fatty Acids in "Terrincho" Ewe Cheese: Intravarietal Comparison
}

\author{
O. Pinho,†’ I. M. P. L. V. O. Ferreira, $\dagger^{\star \star}$ and M. A. Ferreira† \\ †REQUIMTE/Serviço de Bromatologia, Faculdade de Farmácia, \\ Universidade do Porto, Rua Aníbal Cunha, 4050-047 Porto, Portugal \\ ‡Faculdade de Ciências da Nutrição e Alimentação da Universidade do Porto, \\ Rua Dr. Roberto Frias, 4200-465 Porto, Portugal
}

\begin{abstract}
Headspace solid-phase microextraction coupled with gas chromatography-mass spectrometry was employed for the quantification of volatile free fatty acids (FFA) in "Terrincho" ewe cheese. Solid-phase microextraction quantitative analysis was feasible under equilibrium situations as long as the conditions of agitation and the adsorption time were held constant. An excellent linear relationship between the amount of the adsorbed analyte and its initial concentration in the sample matrix was obtained when an adequate amount of sample was chosen. Thus, quantification was possible if biases due to competition or linear range excesses were controlled. Solid-phase microextraction sampling was carried out at $65^{\circ} \mathrm{C}$, and a fiber coated with an $85-\mu \mathrm{m}$ polyacrylate film was chosen. After equilibration at $65^{\circ} \mathrm{C}$ for $40 \mathrm{~min}$, the fiber was exposed to the headspace above the sample for $20 \mathrm{~min}$ and then inserted into the gas chromatograph. The evolution of the volatile FFA during Terrincho ewe cheese ripening was analyzed for a 60 -d period. An overall increase in FFA contents was verified up to $30 \mathrm{~d}$ of ripening. Between 30 and $45 \mathrm{~d}$ most FFA did not suffer significant changes. All FFA increased significantly by the $60-\mathrm{d}$ ripening period. The excessive lipolysis observed at $60 \mathrm{~d}$ of ripening may result in the presence of off-flavors.

Principal component analysis performed for intravarietal comparison of volatile FFA composition of 19 Terrincho cheeses, analyzed at 30 ripening days, enabled discrimination between cheeses produced at five different dairy plants.
\end{abstract}

(Key words: volatile free fatty acid, ewe cheese, ripening)

Abbreviation key: GC/MS = gas chromatography/ mass spectrometry, $\mathbf{H S}=$ headspace, $\mathbf{i}-\mathbf{C}_{\mathbf{4}}=$ isobutanoic acid, $\mathbf{i}-\mathbf{C}_{\mathbf{5}}=$ isopentanoic acid, PCA = principal compo-

Received March 28, 2003.

Accepted May 20, 2003.

Corresponding author: I. M. P. L. V. O. Ferreira; e-mail: isabel. ferreira@ff.up.pt. nents analysis, $\mathbf{P D O}=$ Protected Denomination of Origin, SPME = solid-phase microextraction.

\section{INTRODUCTION}

"Terrincho" ewe cheese is a typical product of the Northeastern region of Portugal. It is a semi-hard cheese, manufactured from raw ewe's milk of the race of "Churra da Terra Quente" according to the specifications of its Protected Denomination of Origin (PDO) Regulatory Board D. N. No. 293/93 (Despacho Normativo, 1993). It undergoes a minimum ripening period of $30 \mathrm{~d}$. This cheese is produced in several dairy plants of the area of Terrincho ewe cheese production (Figure 1). However, it has a different flavor, not only according to the season (grass or hay), but also according to the production site.

A geographical space characterized by a climate and substratum has semi-natural meadow vegetation and agronomic practices. This vegetation is at the base of the ewe's milk production, which is then subject to many different manipulations before becoming a ripened cheese. Along with the intrinsic characteristics of the natural environment, many other factors also intervene, including the farming techniques of the dairy producer and dairy plant site, resulting in different degrees of proteolysis and lipolysis.

Lipolysis is particularly important in raw ewe milk cheeses such as Terrincho, denoted by its high flavor intensity, due to its high fat content and lipase activity (Sablé et al., 1999; Gomez-Ruiz et al. 2002; Larreyoz et al., 2002). Thus, the major flavor of these cheeses comes from short- and medium-chain FFA, which are characteristic odorous compounds of the volatile fraction and contribute to the cheesy, lipolyzed aroma (House et al., 2002; Qian et al., 2002; Thierry et al., 2002; Chamba et al., 2002). However, excessive lipolysis could result in the presence of off-flavors, because high concentrations of volatile FFA influence cheese flavor either directly or as precursors for other compounds (Chávarri et al, 1999).

The objective of the present research was to quantify the volatile FFA during ripening of Terrincho ewe 

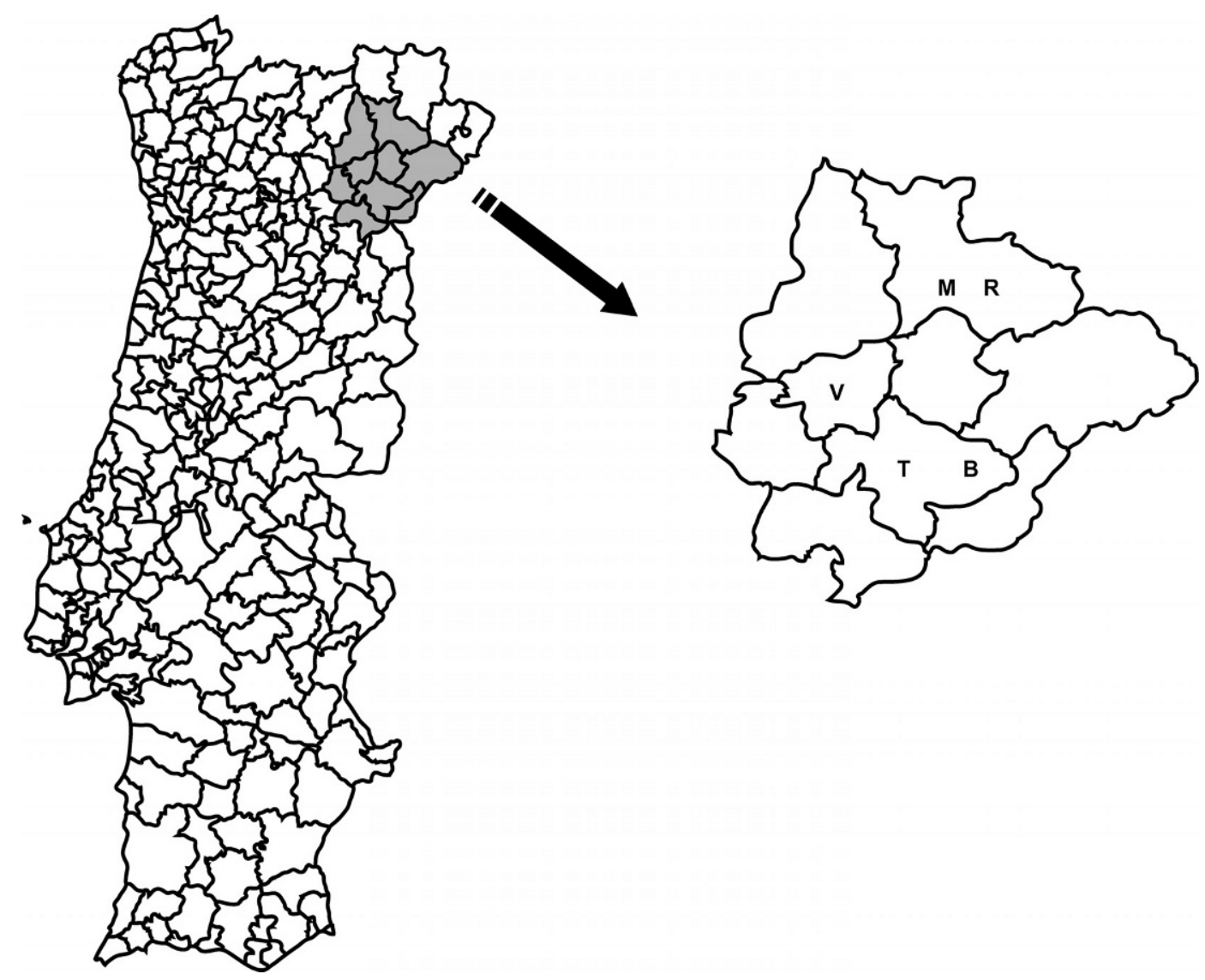

Figure 1. Location of protected origin of Terrincho cheese. $\mathrm{M}$ and $\mathrm{R}$ dairy plants are located at $600 \mathrm{~m}$ of altitude, and V, B, and T dairy plants are located between 400 and $500 \mathrm{~m}$ of altitude.

cheese via utilization of a solid-phase microextraction technique (SPME). A second objective was to study FFA contents of Terrincho cheeses from the same cheesemaking season (winter) but manufactured in different dairy plants. Few available studies on other cheeses indicate that there are substantial intravarietal differences with respect to short-chain FFA (Fox et al., 2000).

The application of SPME for FFA analysis in cheese has been largely explored by many researchers (Chin et al., 1996; Wijesundera et al., 1998; Pinho et al. 2001; González-Cordona et al., 2001; Pinho et al., 2002). The analytical method used for quantification of FFA was previously optimized and validated (Pinho et al., 2002) and involved extraction of FFA from ewe cheese by headspace- (HS) SPME prior to gas chromatography/ mass spectrometry (GC/MS), which required minimum sample manipulation, without time-consuming steps. This previous study verified that SPME quantitative analysis was not feasible under equilibrium situations as long as the conditions of agitation and the adsorption time were held constant. An excellent linear relationship between the amount of the adsorbed analyte and its initial concentration in the sample matrix was obtained when an adequate amount of sample was chosen. Thus, quantification by HS-SPME-GC/MS was possible if biases due to competition or linear range excesses were controlled (Roberts et al., 2000; Pinho et al., 2002).

\section{MATERIALS AND METHODS}

\section{Reagents}

Propanoic $\left(\mathrm{C}_{3}\right)$ isobutanoic $\left(\mathbf{i}-\mathbf{C}_{4}\right)$, butanoic $\left(\mathrm{C}_{4}\right)$, pentanoic $\left(\mathrm{C}_{5}\right)$ isopentanoic $\left(\mathbf{i}-\mathbf{C}_{5}\right)$, hexanoic $\left(\mathrm{C}_{6}\right)$, octanoic $\left(\mathrm{C}_{8}\right)$, pelargonic $\left(\mathrm{C}_{9}\right)$, decanoic $\left(\mathrm{C}_{10}\right)$, and tetradecanoic $\left(\mathrm{C}_{14}\right)$ acids were purchased from Sigma (St. Louis, MO). Ethanoic $\left(\mathrm{C}_{4}\right)$ and dodecanoic $\left(\mathrm{C}_{11}\right)$ acids were purchased from Aldrich (Steinhein, Germany). Dichloromethane and mineral oil were purchased from Fluka (Buchs, Switzerland). Sodium sulphate and sodium chloride were purchased from Merck (Darmstadt, Germany).

Standard stock solutions of FFA $1000 \mu \mathrm{g} / \mathrm{ml}$ were prepared in dichloromethane and stored at $-20^{\circ} \mathrm{C}$. 


\section{Cheese Making}

In agreement with specified professionals (veterinarians, farmers, cheese makers, and marketing agents), five dairy plants located in Northeastern Portugal were selected for the quality and consistency of Terrincho cheese production (Figure 1). The dairy plants that were selected corresponded to producers with similar agricultural practices, and the area under study was representative of its production.

A total of 47 Terrincho ewe cheeses were manufactured at these different dairy plants according to two different experimental designs described as follows: 1) a batch of 28 Terrincho ewe cheeses, from which groups of four cheeses were analyzed at $0,6,13,21,30,45$, and $60 \mathrm{~d}$ of ripening; and 2) five other batches of Terrincho ewe cheeses, each from one of five different dairy plants (V, M, T, B, and R), all produced during the same cheese-making season (winter) and all ripened for 30 $\mathrm{d}$ (the minimum recommended ripening time). All such cheese samples were coded with a letter $(\mathrm{V}, \mathrm{M}, \mathrm{T}, \mathrm{B}$, and $\mathrm{R}$ ) corresponding to the respective dairy plant and a number (1 to 4 ) that represented each of the four cheeses within the same batch. Only three cheeses were available from $\mathrm{R}$ dairy plant, thus, 19 cheeses were analyzed in this second design group.

\section{General SPME Procedures}

Sample preparation and SPME procedures were carried out as previously optimized (Pinho et al., 2002). Cheese samples were placed in $15-\mathrm{ml}$ vials containing $1 \mathrm{~g}$ of sodium sulphate in order to obtain a homogenous nonsticky granular powder and a magnetic stir bar and were subsequently sealed with PTFE/Silicone septa.

Solid-phase microextraction sampling was carried out at $65^{\circ} \mathrm{C}$; a fiber coated with an $85-\mu \mathrm{m}$ polyacrylate film was chosen. After equilibration at $65^{\circ} \mathrm{C}$ and for 40 min, the fiber was exposed to the HS above the sample for 20 min and then inserted into the GC.

\section{Gas Chromatography/Mass Spectrometry}

Gas chromatographic analysis was carried out using a Hewlett-Packard (HP) model 6890 GC fitted with a split/splitless injector suitable for SPME analysis and an Agilent 5973 MS detector. Helium was used as the carrier gas with a flow rate of $0.8 \mathrm{ml} / \mathrm{min}$. The components were separated on a $30 \mathrm{~m} \times 0.25 \mathrm{~mm}$ i.d. 0.25 $\mu \mathrm{m}$ film DB-Wax column from $\mathrm{J}(\mathrm{W}$ (http://www.chem. agilent.com/cag/cabu/jandw.htm). The injector temperature was set at $220^{\circ} \mathrm{C}$ and in split mode (split ratio: 10:1); the injection port was equipped with a narrowbore $(0.75 \mathrm{~mm}$ i.d.) glass liner (Supelco) to minimize peak broadening.
The column was initially maintained at $40^{\circ} \mathrm{C}$ for 10 min, and the temperature was subsequently increased to $250^{\circ} \mathrm{C}$ at a rate of $10^{\circ} \mathrm{C} / \mathrm{min}$, temperature that was then held for a further 9 min (total program time 40 $\min$ ).

The volatile components were detected by mass spectrometry with electron impact ionization at $70 \mathrm{eV}$. Compounds were identified by matching mass spectra with the NBS library of standard compounds. Mass spectrometric identification was further confirmed by comparing GC retention times with those of authentic compounds.

\section{Chemical Analyses}

Total fat content in cheese was determined by the Van Gulik method (ISO 3432-1975 and 3433-1975), and moisture content was determined by Infratest, Saltec Instruments GmbH, SMO 01.

\section{Sensory Analysis}

A panel composed of seven members performed sensory analysis. Subjects were selected (two sessions) for their sensory ability and trained (11 sessions) for descriptive analysis according to the guidelines in the ISO 6564:1985 standard flavor profiles. Odor was defined as the olfactory sensation felt directly by the nose. Aroma was defined as the olfactory sensation felt the retronasal way upon mastication.

As suggested by Carbonell et al (2002), panelists were asked to give a classification on a 0- to 7-point scale for quality and intensity of odor and aroma and a final overall appreciation (7 points for most disagreeable).

\section{Statistical Analysis}

Descriptive statistics analysis of variance (ANOVA) using $95 \%$ confidence intervals, pair-wise comparisons of mean values with Fisher's LSD test, and principal components analysis (PCA) were performed with Systat for Windows version 10.0 (SPSS Inc, Chicago, IL).

Intravarietal comparison for Terrincho cheese was performed by PCA, which was conducted to determine similarities/differences between cheeses from different dairy plants considering all the variables under study. Data were standardized, with $\mathrm{N}=19$ rows corresponding to 19 volatile FFA profiles $(4 \mathrm{~V}, 4 \mathrm{M}, 4 \mathrm{~T}, 3 \mathrm{R}$, and $4 \mathrm{~B})$ and the column vectors $\left(\mathrm{x}_{1}, \mathrm{x}_{2} \ldots x i, \mathrm{x}_{8}\right)$ representing the following fatty acids $\mathrm{C}_{2}, \mathrm{i}-\mathrm{C}_{4}, \mathrm{C}_{4}, \mathrm{i}-\mathrm{C}_{5}, \mathrm{C}_{6}, \mathrm{C}_{8}, \mathrm{C}_{10}$, and $\mathrm{C}_{11}$.

A categorical PCA was performed to correlate the concentration of FFA with sensory characteristics of Terrincho cheeses from the five dairy plants. This proce- 

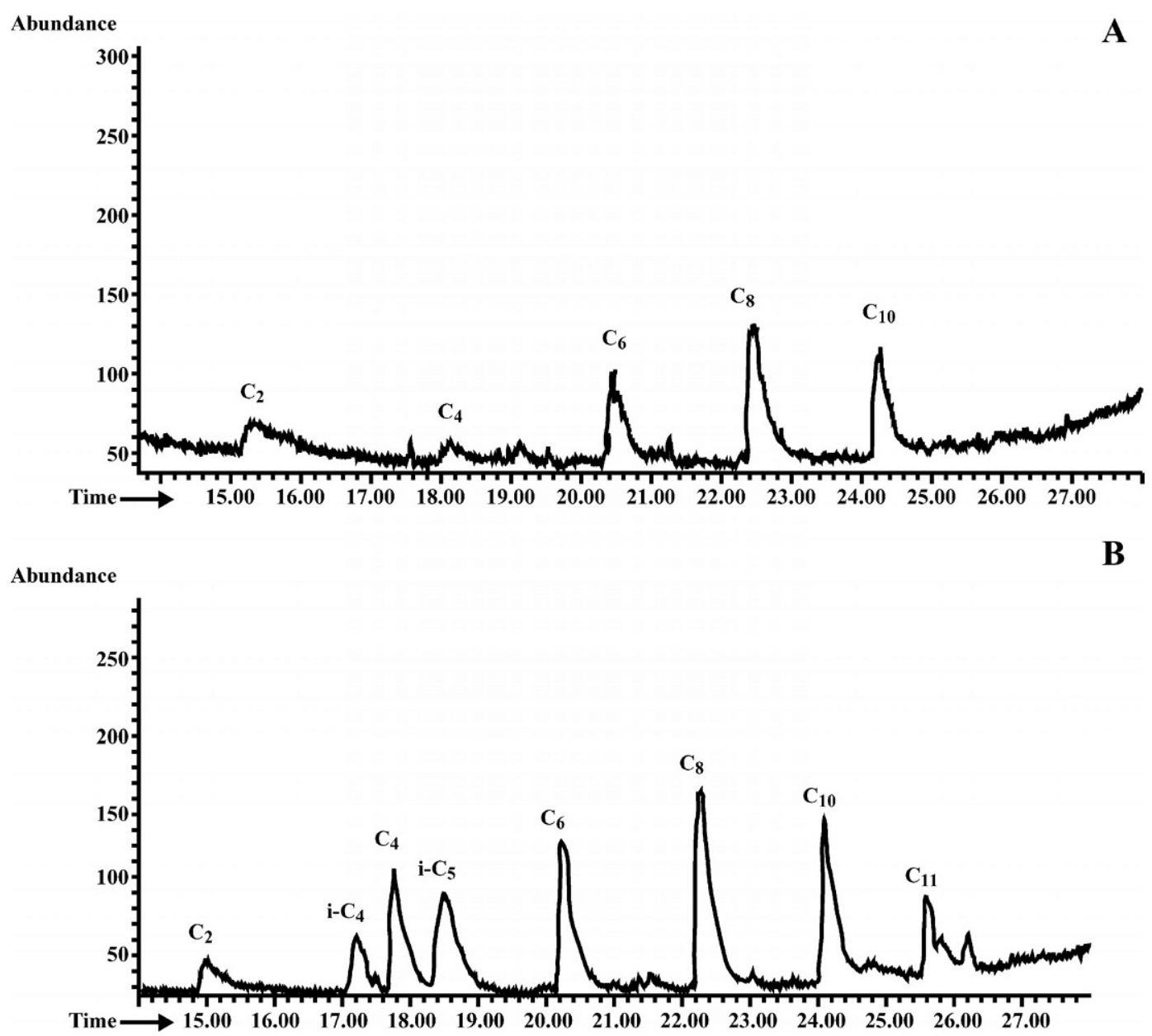

Figure 2. Typical chromatograms obtained for A) $0.5 \mathrm{~g}$ of a cheese sample by $6 \mathrm{~d}$ of ripening and B) $0.03 \mathrm{~g}$ of a cheese sample by $60 \mathrm{~d}$ of ripening.

dure simultaneously quantified categorical variables while reducing the dimensionality of the data. The optimal-scaling approach allowed to be scaled at different levels.

\section{RESULTS AND DISCUSSION}

\section{Evolution of Volatile FFA During Ripening}

According to the FFA content of each cheese, an adequate sample amount was chosen to obtain a linear relationship between the amount of analyte adsorbed by the SPME polymer film and the initial concentration of the analyte in the cheese sample.

Figure 2 shows typical chromatograms obtained for 6- and 60-d ripening, using different sample amounts.

The standard addition method (Pinho et al., 2002) was used for quantification of the major FFA acids in Terrincho cheese during ripening. The results obtained for $\mathrm{C}_{2}, \mathrm{i}-\mathrm{C}_{4}, \mathrm{C}_{4}, \mathrm{i}-\mathrm{C}_{5}, \mathrm{C}_{6}, \mathrm{C}_{8}, \mathrm{C}_{10}$, and $\mathrm{C}_{11}$ are summarized in Table 1. Other minor FFA that were identified but were not quantified included $\mathrm{C}_{3}, \mathrm{C}_{5}, \mathrm{C}_{9}$, and $\mathrm{C}_{14}$.

A marked increase in the concentration of FFA was observed during cheese ripening, an observation confirmed by analysis of variance that indicated significant differences in volatile FFA contents during ripening $(P$ $\leq 0.0001)$. At $60 \mathrm{~d}$ of ripening, the major FFA were $\mathrm{C}_{8}$, $\mathrm{C}_{10}$, and $\mathrm{C}_{4}$ (Figure 3 ).

No significant differences were found between the contents of these FFA at 0,6 , and 13 d. However, between 30 and $60 \mathrm{~d}$ of ripening, the release of these FFA was very prominent, especially for $\mathrm{C}_{8}$ and $\mathrm{C}_{10}$. The remaining FFA $\left(\mathrm{C}_{2}, \mathrm{i}-\mathrm{C}_{4}, \mathrm{i}-\mathrm{C}_{5}, \mathrm{C}_{6}\right.$, and $\left.\mathrm{C}_{11}\right)$ also increased significantly during ripening; however, at 60 $\mathrm{d}$ their contents were not as high as $\mathrm{C}_{8}$ and $\mathrm{C}_{10}$ contents (Figure 4).

The release of $\mathrm{C}_{2}$ and $\mathrm{C}_{11}$ presented similar behavior. A significant increase was observed at 13,21 , and $30 \mathrm{~d}$ of ripening and again at $60 \mathrm{~d}$. There were no significant 
Table 1. Free fatty acid concentrations in Terrincho ewe cheeses throughout a 60-d ripening period.

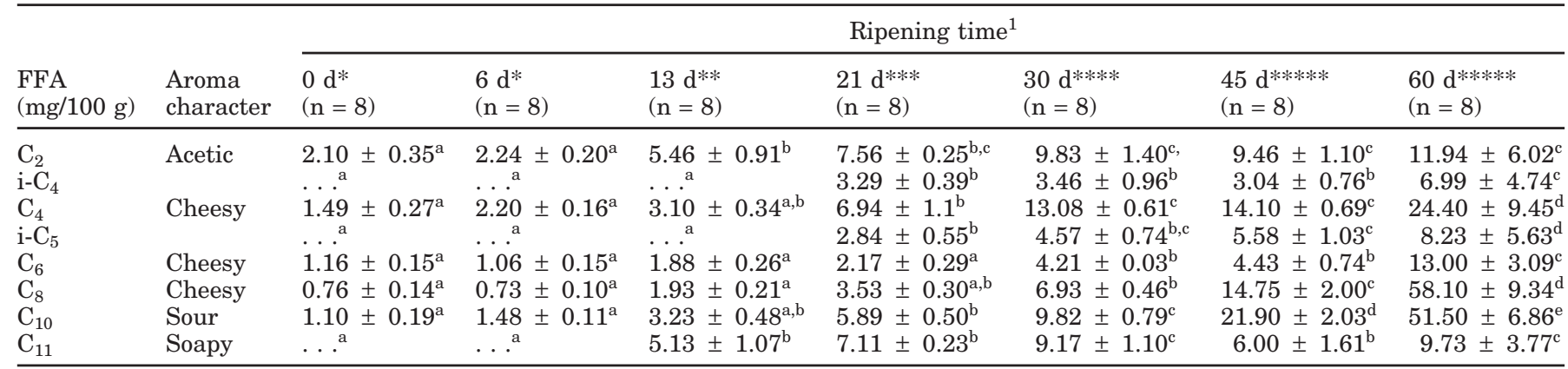

${ }^{\mathrm{a}, \mathrm{b}, \mathrm{c}}$ Means within rows with different superscripts are statistically different $(P<0.05)$.

${ }^{1}$ Sample amount used was $* 0.5 \mathrm{~g}, * * 0.25 \mathrm{~g}, * * * 0.125 \mathrm{~g}, * * * * 0.05 \mathrm{~g}$, and $* * * * * 0.03 \mathrm{~g}$ of cheese. Values are expressed as mean $\pm \mathrm{SD}(\mathrm{n}=$ 16 , four cheeses analyzed in quadruplicate).

differences in $\mathrm{i}-\mathrm{C}_{4}, \mathrm{i}-\mathrm{C}_{5}$, and $\mathrm{C}_{6}$ content at 0,6 , and 13 $\mathrm{d}$ of ripening. A slight increase was noted between 21 and $45 \mathrm{~d}$ of ripening, followed by a significant increase at $60 \mathrm{~d}$. High concentrations of volatile FFA have also been found in other PDO ewe cheeses as described by Macedo and Malcata (1996) and Gomez-Ruiz et al. (2002). Similar increase in the percentage of volatile FFA to those reported in this work were described in other ovine PDO cheeses, such as Serra (Macedo and Malcata, 1996) and Picante cheese (Freitas and Malcata, 1996), and Idiazabal (Chávarri et al, 1999).

\section{Intravarietal Comparison at 30 Ripening Days}

The results obtained for quantification of FFA in Terrincho cheeses from five different dairy plants, at 30 $\mathrm{d}$ of ripening (period recommended by legislation) are depicted in Table 2.

Intravarietal comparison of these five batches of Terrincho cheese was carried out by PCA. As shown in Table 3, communalities among the variables were high, ranging from 0.653 to 0.973 . Therefore, PCA could be

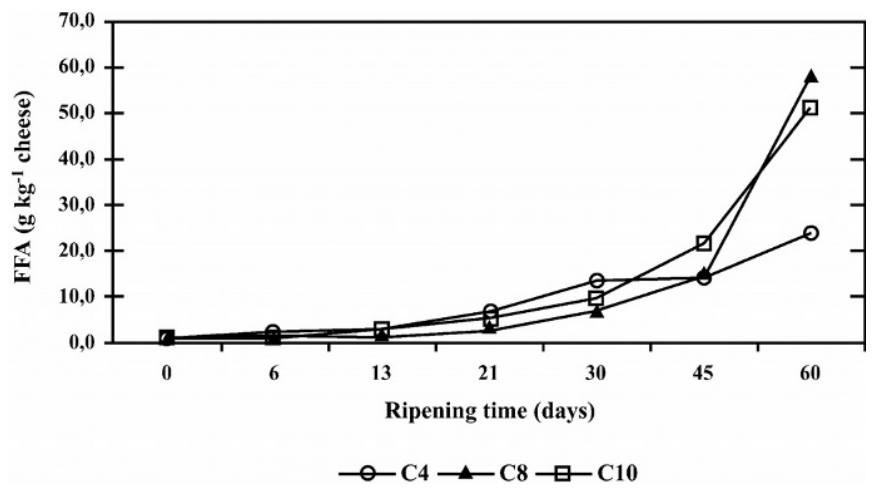

Figure 3. Evolution of $\mathrm{C}_{4}, \mathrm{C}_{8}$, and $\mathrm{C}_{10}$ during ripening of Terrincho cheese. applied to the results without deterioration or loss of information.

The PCA of analytical variables resulted in five principal components with eingenvalues higher than 1.0. The first two principal components took into account $87.5 \%$ of the total variation. Thus, the dimensionality of the results was reduced from eight variables to two principal components, with $12.5 \%$ loss of variance. The first component (PC1) by itself condensed almost $60 \%$, and the second component ( $\mathrm{PC} 2$ ) represented $27.9 \%$ of the total information.

Loading coefficients obtained from the application of PCA to the data are shown in Table 3. Component PC1 was high in $\mathrm{C}_{8}, \mathrm{C}_{11}, \mathrm{C}_{6}, \mathrm{C}_{4}, \mathrm{C}_{2}$, and $\mathrm{C}_{10}$. Component PC2 was high in i- $\mathrm{C}_{4}$ and $\mathrm{i}-\mathrm{C}_{5}$.

The scores of all Terrincho cheese samples as a function of the first two principal components are plotted in Figure 5. In this figure, the most important volatile FFA needed for the definition of these components are also shown on the axis' edges, indicating the direction

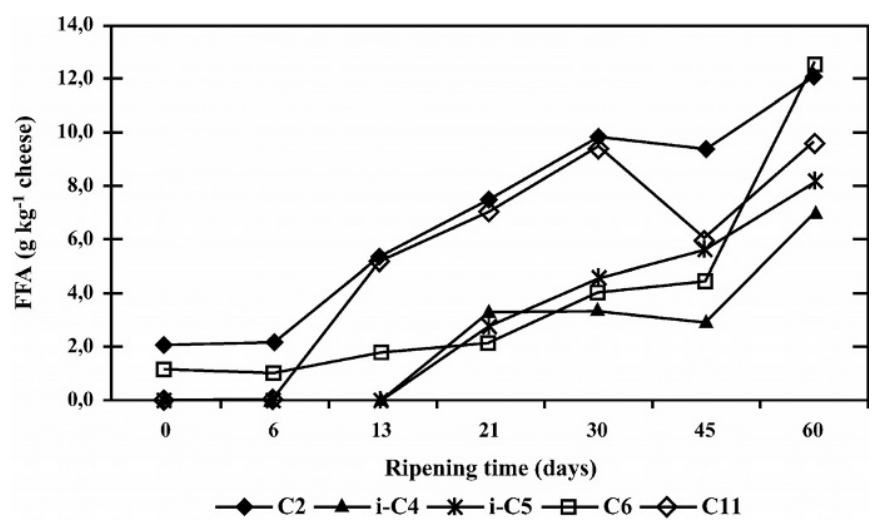

Figure 4. Evolution of $\mathrm{C}_{2}, \mathrm{iC}_{4}, \mathrm{iC}_{5}, \mathrm{C}_{6}$, and $\mathrm{C}_{11}$ during ripening of Terrincho cheese. 
Table 2. Free fatty acid concentrations of Terrincho cheeses from different dairy plants by $30 \mathrm{~d}$ of ripening.

\begin{tabular}{|c|c|c|c|c|c|}
\hline \multirow{2}{*}{$\begin{array}{l}\text { FFA } \\
(\mathrm{mg} / 100 \mathrm{~g})\end{array}$} & \multicolumn{5}{|c|}{ Dairy plants ${ }^{1}$} \\
\hline & $\mathrm{V}$ & $\mathrm{R}$ & $\mathrm{T}$ & B & M \\
\hline $\mathrm{C}_{2}$ & $9.22 \pm 2.18$ & $14.15 \pm 2.84$ & $22.99 \pm 3.69$ & $10.23 \pm 1.17$ & $9.83 \pm 1.51$ \\
\hline $\mathrm{i}-\mathrm{C}_{4}$ & & & & $1.19 \pm 0.68$ & $3.46 \pm 0.96$ \\
\hline $\mathrm{C}_{4}$ & $19.65 \pm 3.94$ & $12.17 \pm 4.24$ & $34.85 \pm 3.07^{\mathrm{c}}$ & $19.71 \pm 5.4$ & $13.08 \pm 0.81$ \\
\hline $\mathrm{i}-\mathrm{C}_{5}$ & & & & $1.49 \pm 1.22$ & $4.57 \pm 0.73$ \\
\hline $\mathrm{C}_{6}{ }^{\circ}$ & $2.10 \pm 0.56$ & $0.83 \pm 0.27$ & $5.84 \pm 0.44$ & $1.45 \pm 0.48$ & $4.21 \pm 0.03$ \\
\hline $\mathrm{C}_{8}$ & $3.76 \pm 0.66$ & $1.13 \pm 0.59$ & $21.02 \pm 1.82$ & $1.53 \pm 0.42$ & $6.93 \pm 0.5$ \\
\hline $\mathrm{C}_{10}$ & $10.17 \pm 1.16$ & $2.77 \pm 1.19$ & $11.69 \pm 1.02$ & $2.67 \pm 0.74$ & $9.82 \pm 0.77$ \\
\hline $\mathrm{C}_{11}$ & $3.68 \pm 1.12$ & $3.75 \pm 1.55$ & $26.51 \pm 4.53$ & $0.386 \pm 0.72$ & $9.17 \pm 1.20$ \\
\hline
\end{tabular}

${ }^{1}$ Sample amount used was $\mathrm{T}=0.02 \mathrm{~g}, \mathrm{~V}=0.05 \mathrm{~g}, \mathrm{M}, \mathrm{R}$, and $\mathrm{B}=0.12 \mathrm{~g}$. Values are expressed as mean \pm $\mathrm{SD}(\mathrm{n}=16$, four cheeses analyzed in quadruplicate, except for $\mathrm{R}$ dairy plant for $\mathrm{n}=12$, three cheeses analyzed in quadruplicate).

in which the values of fatty acids increase, as is conventionally done in any PCA.

Differences were observed between $\mathrm{M}$ cheeses, $\mathrm{T}$ cheeses, and the remaining three groups of cheeses. Component PC1 separated T cheeses from all the others. The $\mathrm{T}$ cheeses registered the highest content of $\mathrm{C}_{8}$, $\mathrm{C}_{11}, \mathrm{C}_{6}, \mathrm{C}_{4}$, and $\mathrm{C}_{10}$. All $\mathrm{T}$ cheeses were located at the right side of the map. The $\mathrm{M}$ cheeses differed from all the other counterparts on PC2. All M cheeses were located at the top of the map. They exhibited the highest content of $\mathrm{i}-\mathrm{C}_{4}$ and $\mathrm{i}-\mathrm{C}_{5}$.

Differences within $\mathrm{B}, \mathrm{V}$, and $\mathrm{R}$ cheeses were lower. The cheeses produced at these three dairy plants presented different profiles from the other two groups, $T$ and M. Thus, PCA was calculated without the M and $\mathrm{T}$ cheeses in order to be able to discriminate those groupings (Figure 6). In the latter case, $\mathrm{PC} 1$ was high in $\mathrm{C}_{8}$ and $\mathrm{C}_{10}$ (positive values) and in $\mathrm{iC}_{4}$ and $\mathrm{iC}_{5}$ (negative values). $\mathrm{PC} 2$ was high in $\mathrm{C}_{4}$ (positive value) and $\mathrm{C}_{2}$ (negative value); Figure 6 shows a clustering of $\mathrm{B}, \mathrm{R}$, and $\mathrm{V}$ cheeses.

Intravarietal comparison of volatile FFA composition of Terrincho cheeses from the same season showed that it was possible to distinguish cheeses produced on different dairy plants. It is interesting to point out that, although these cheeses presented total fat and moisture contents similarly, approximately 28 to $30 \%$ and 45 to

Table 3. Principal components (PC) rotated loading for characteristic FFA.

\begin{tabular}{llrl}
\hline FFA & PC1 & PC2 & Communalities \\
\hline $\mathrm{C}_{8}$ & 0.976 & 0.140 & 0.973 \\
$\mathrm{C}_{11}$ & 0.964 & 0.131 & 0.947 \\
$\mathrm{C}_{6}$ & 0.874 & 0.457 & 0.972 \\
$\mathrm{C}_{4}$ & 0.857 & -0.265 & 0.805 \\
$\mathrm{C}_{2}$ & 0.852 & -0.216 & 0.772 \\
$\mathrm{C}_{10}$ & 0.709 & 0.388 & 0.653 \\
$\mathrm{i}-\mathrm{C}_{4}$ & -0.288 & 0.930 & 0.932 \\
i-C $_{5}$ & -0.279 & 0.924 & 0.948 \\
\hline
\end{tabular}

$48 \%$, respectively, they received different classification in the sensory analysis. The $\mathrm{T}$ cheeses presented the highest FFA contents, and, in sensory analysis, they received the highest classification for odor and aroma intensity (4.9 and 5.1 points, respectively). Concerning global appreciation, $\mathrm{T}$ cheeses were considered the most disagreeable (5.8 points). Slight differences of flavor were observed between cheeses from the other dairy plants.

The results from categorical PCA performed to correlate the concentration of FFA with sensory characteristics of Terrincho cheeses from the five dairy plants have been depicted on a two-dimensional plot (Figure 7) that explained $93.8 \%$ of the total variance in data. The Dimension $1(\mathrm{k}=10.1)$ explained $77.9 \%$ of the variance

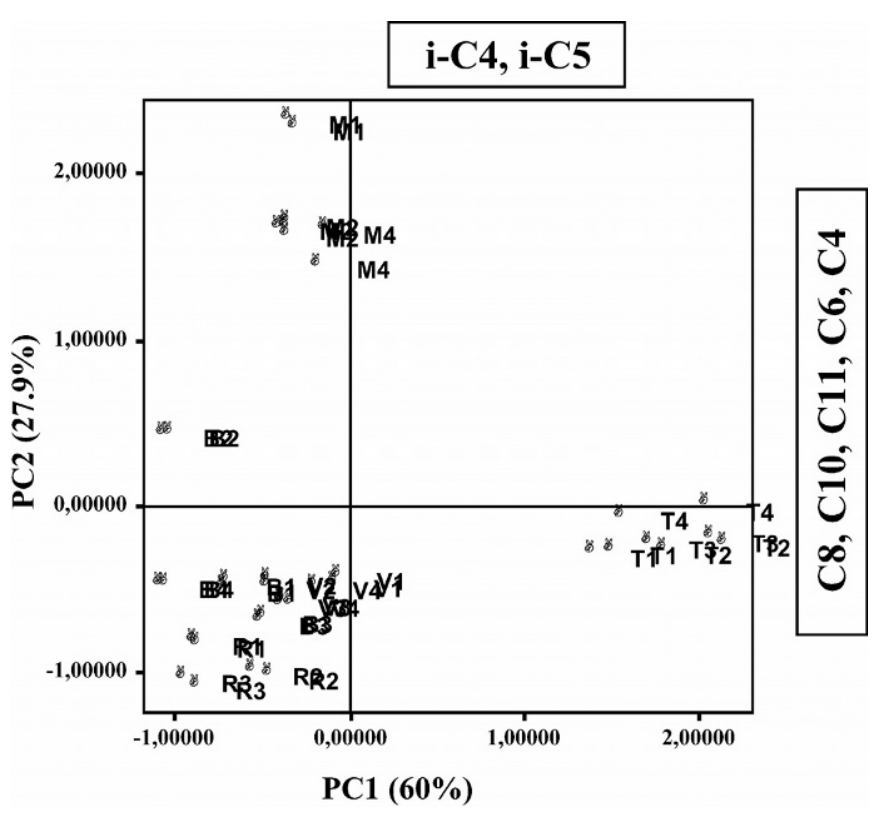

Figure 5. Scores of five batches of Terrincho cheese samples (V, $\mathrm{R}, \mathrm{T}, \mathrm{B}, \mathrm{M})$ on the two principal components. 


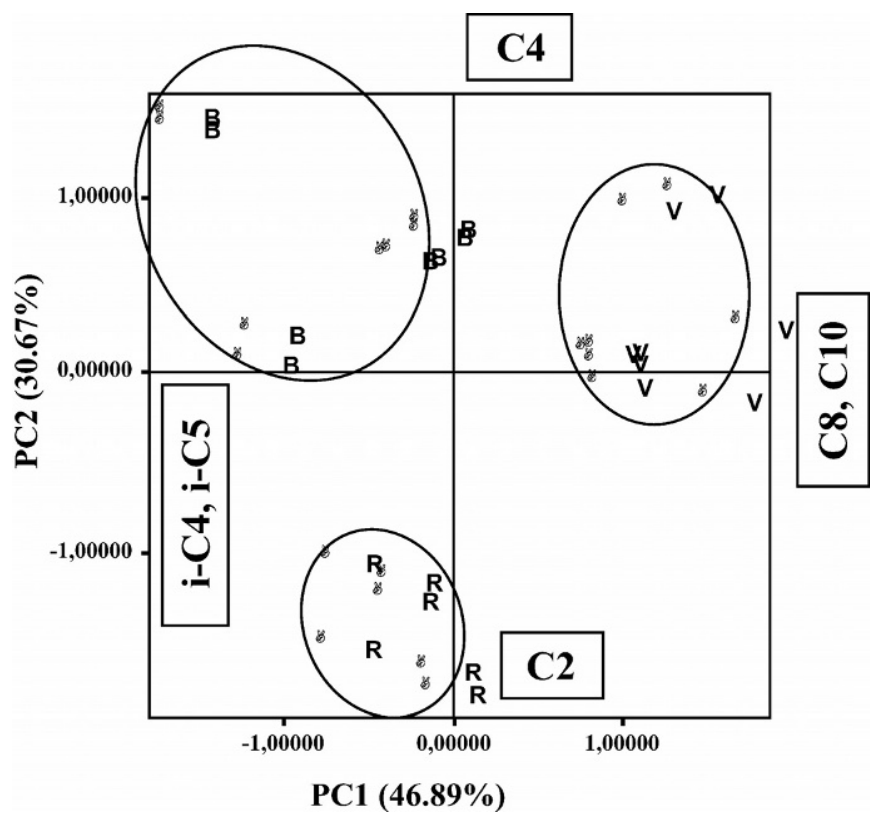

Figure 6. Scores of three batches of Terrincho cheese samples $(\mathrm{V}$, $\mathrm{R}, \mathrm{B}$ ) on the two principal components.

in data. The positive segment of the plot for Dimension 1 was related to the increase of FFA contents and intensity of odor and aroma together with disagreeability.

The release of many FFA in cheese may be the outcome of the lipolytic activity of microorganisms. In

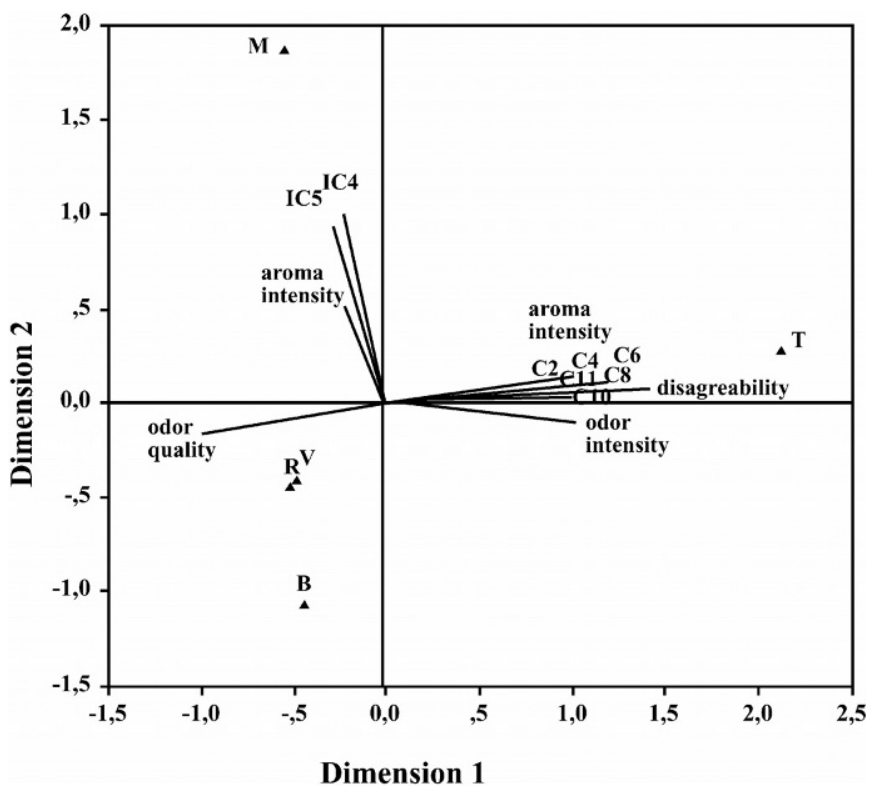

Figure 7. Categorical principal component analysis biplot showing relationship between mean values of FFA contents of cheese samples from five different dairy plants $(\mathrm{V}, \mathrm{R}, \mathrm{T}, \mathrm{B}, \mathrm{M})$ and respective sensory attributes. many cases, there is a significant influence of microflora origin on the characteristics of cheeses. It is well established that advantageous microflora play an important role in the biochemical and sensory characteristics of raw-milk cheeses, especially as regards facultatively heterofermentative lactobacilli. Further work in this area appears to be warranted.

Comprehension of these relationships implies characterization of the microbiological profiles of all cheeses and thereafter determines their role in lipolysis. Such work is presently being undertaken.

\section{CONCLUSIONS}

Quantitative analysis of volatile FFA in Terrincho cheese was efficiently performed by HS-SPME-GC/MS.

During ripening of Terrincho cheese, important changes in the volatile FFA took place. There was an overall increase in volatile FFA contents, an observation that was in good agreement with the results reported for other kinds of ewe milk cheeses.

From a chemical point of view, the best period to interrupt Terrincho cheese ripening was between 30 and $45 \mathrm{~d}$, where most FFA had not yet suffered significant changes. All volatile FFA presented a significant increase between 45 and $60 \mathrm{~d}$. The excessive lipolysis observed by $60 \mathrm{~d}$ of ripening could result in the presence of off-flavors.

In what concerns intravarietal comparison, the differences between Terrincho cheeses produced at the same dairy plant were globally lower than differences between cheeses produced at different dairy plants; such differences were noted in sensory analyses.

\section{REFERENCES}

Chamba, J. F., and E. Perreard. 2002. Contribution of propionic acid bacteria to lipolysis of Emmental cheese. Lait 82:33-34.

Chávarri, F., M. A. Bustamante, A. Santisteban, M. Virto, L. J. R Barrón, and M. Renobales, 1999. Changes in free fatty acids during ripening of Idiazabal cheese manufactured at different times of the year. J. Dairy Sci. 82:885-890.

Chin, H., W., R. A. Bernhard, and M. Rosenberg. 1996. Solid-phase microextraction for cheese volatile compound analysis. J. Food Sci. 61:1118-1112.

Carbonell, M., M. Nuñez, and E. Fernández-Garcia. 2002. Evolution of the volatile components of ewe raw milk la Serena cheese during ripening. Correlation with flavour characteristics. Lait 82:683-698.

Despacho Normativo. 293/93 from 1 October 1993, D. R. I Série B$\mathrm{n}^{0} 231$.

Fox, P. F., T. P. Guinee, T. M. Cogan, and P. L. H. McSweeney. 2000. Fundamentals of Cheese Science: Cheese Flavor. Aspen Publishers, Inc., Gaithersburg, MD.

Freitas, A. C., J. M. Fresno, B. Prieto, F. X. Malcata, and J. Carballo. 1997. Effects of ripening time and combination of ovine and caprine milks on proteolysis of Picante. Food Chem. 60:219-229.

Gomez-Ruiz, J. A., C. Ballesteros, M. A. G. Vinas, L. Cabezas, and I. Martinez-Castro. 2002. Relationships between volatile compounds and odour in Manchego cheese: Comparison between arti- 
sanal and industrial cheeses at different ripening times. Lait 82:613-628.

González-Cordova, A. F., and B. Vallejo-Cordoba. 2001. Quantitative determination of short-chain free fatty acids in milk using solidphase microextraction and gas chromatography. J. Agric. Food Chem. 49:4603-4608.

House, K. A., and T. E. Acree. 2002. Sensory impact of free fatty acids on the aroma of a model Cheddar cheese. Food Qual. Preference 13:481-488.

Larrayoz, P., C. Mendia, P. Torre, Y. Barcina, and I. Ordonez. 2002. Sensory profile of flavour and odor characteristics in roncal cheese made from raw ewěs milk. J. Sensory Stud. 17:415-427.

Macedo, A. C., and F. X. Malcata. 1996. Changes in the major free fatty acids in Serra cheese throughout ripening. Int. Dairy J. 6:1087-1097.

Organisation International de Normalisation, ISO, 3432-1975-Fromages. Determination de la teneur en matière grasse. Butyromètre pour la méthode Van Gulik.

Organisation International de Normalisation, ISO, 3433-1975-Fromage. Détermination de la teneur en matière grasse. Méthode Van Gulik.

Organisation International de Normalisation, ISO, 6564:1985 Analyse sensorielle- Methodologie- Méthodes détablissement du profil de la flaveur.
Pinho, O., I. M. P. L. V. O. Ferreira, S. Casal, J. O. Fernandes, M. B. P. P. Oliveira, and M. A. Ferreira. 2001. Method optimization for analysis of the volatile fraction of ewe cheese by solid-phase microextraction. Chromatographia 53(Suppl.):S390-S393.

Pinho, O., I. M. P. L. V. O. Ferreira, and M. A. Ferreira. 2002. Solidphase microextraction in cmbination with GC/MS for qantification of the major volatile free fatty acids in ewe cheese. Analyt. Chem. 74:5199-5204.

Qian, M., and G. Reineccius. 2002. Identification of aroma compounds in Parmigiano-Reggiano cheese by gas chromatography/olfactometry. J. Dairy Sci. 85:1362-1369.

Roberts, D. D., P. Pollien, and C. Milo. 2000. Solid-phase microextraction method development for headspace analysis of volatile flavor compounds. J. Agric Food Chem. 48:2430-2437.

Sablé, S., and G. Cottenceau. 1999. Current knowledge of soft cheeses flavour and related compounds. J. Agric. Food Chem. 47:48254836.

Thierry, A., and M. B. Maillard. 2002. Production of cheese flavour compounds derived from amino acid catabolism by Propionibacterium freudenreichii. Lait 82:17-32

Wijesundera, C., L. Drury, and T. Walsh. 1998. Determination of free fatty acids and lactones in cheese by solid-phase microextraction (SPME). Aust. J. Dairy Technol. 53:146. 